\title{
Reuna
}

\section{LEI DE RESPONSABILIDADE FISCAL: UMA FERRAMENTA ESTRATÉGICA PARA O DESENVOLVIMENTO DO ESTADO DE ALAGOAS}

\section{FISCAL RESPONSIBILITY LAW: A STRATEGIC TOOL FOR THE DEVELOPMENT OF THE STATE OF ALAGOAS}

http://dx.doi.org/10.21714/2179-8834/2017v22n4p65-88

\author{
Diego Oliveira \\ Universidade Federal de Alagoas (UFAL), Faculdade de Economia, Administração e Contabilidade, Brasil. \\ E-mail: fariasoliveira@gmail.com
}

\author{
Waldemar Antonio da Rocha Souza \\ Universidade Federal de Alagoas (UFAL), Faculdade de Economia, Administração e Contabilidade, Brasil. \\ E-mail: prof.wsouza@gmail.com
}

Submissão: 06 Out. 2016 Publicação: 29 Dez. 2017. Sistema de avaliação: Double blind review. Centro Universitário UNA, Belo Horizonte - MG, Brasil. Editor geral: Prof. Dr. Gustavo Quiroga Souki

Este artigo encontra-se disponível nos seguintes endereços eletrônicos:

http://revistas.una.br/index.php/reuna/article/view/813

http://dx.doi.org/10.21714/2179-8834/2017v22n4p65-88

\section{RESUMO}

Esta pesquisa tem como objetivo analisar a Lei de Responsabilidade Fiscal (LRF), como uma ferramenta gerencial estratégica para impulsionar o desenvolvimento econômico e social do Estado de Alagoas. Assim, esta pesquisa tem início com exposição de conceitos da Lei de Responsabilidade Fiscal como instrumento para tomada de decisão pelo chefe do Poder Executivo na implementação de políticas públicas, ao longo dos anos, desde sua implementação até 2017. Com base nesta fundamentação teórica, normativa, verifica-se que a LRF possui uma gama de ferramentas estratégicas: balanços orçamentários, patrimoniais, financeiros, planos plurianuais, diretrizes, leis orçamentárias, relatórios e anexos. Por outro lado, não sendo utilizada apenas como um mero documento formal no cumprimento da legalidade. Por fim, esta pesquisa visa identificar as ferramentas da LRF na tomada de decisões estratégicas pelo chefe do Poder Executivo de Alagoas, com a finalidade de fornecer bases para futuros estudos mais aprofundados sobre ferramentas estratégicas para o setor público. Conclui-se a pesquisa apontando algumas considerações sobre a importância da utilização, em rede, de todas as ferramentas estratégicas na Administração Pública.

Palavras-chave: Lei de Responsabilidade Fiscal. Finanças Públicas. Dívida Pública. Prestação de contas. 


\section{ABSTRACT}

This research aims to analyze the Fiscal Responsibility Law (LRF) as a strategic management tool to boost the economic and social development of the State of Alagoas. Thus, this research begins with the presentation of concepts of the Fiscal Responsibility Law as an instrument for decision making by the head of the Executive Branch in the implementation of public policies, over the years, from its implementation until 2017. Based on this theoretical, normative foundation, it can be seen that the LRF has a range of strategic tools: budget, patrimonial, financial, multi-year plans, guidelines, budget laws, reports and annexes. On the other hand, it is not used merely as a formal document in compliance with legality. Finally, this research aims to identify the tools of the LRF in strategic decision making by the head of the Executive Branch of Alagoas, with the purpose of providing bases for further studies on strategic tools for the public sector. The research concludes by pointing out some considerations about the importance of the network use of all the strategic tools in Public Administration.

Keywords: Fiscal Responsibility Law. Public finances. Public debt. Accountability.

\section{Introdução}

No dia 4 de maio de 2000, foi publicada a Lei de Responsabilidade Fiscal (LRF), uma lei complementar de abrangência nacional, isto é, vinculada a todos os entes federados. Com fundamento legal de regulamentar os artigos 163 e 169 da Constituição da República Federativa do Brasil (CRFB) de 1988. O referido dispositivo legal tem como um dos seus principais objetivos o controle do endividamento, em todos os níveis de governo, também se apresenta como um marco histórico para a sociedade brasileira, em decorrência do descontrole orçamentário e dos elevados déficits públicos.

Nesse diapasão, como as contas externas do Brasil, em 1999, não fechavam (AVERBUG e GIAMBIAGI, 2000), a pressão do Fundo Monetário Internacional fez que - Congresso Nacional aprovasse a LRF, apesar do lobismo de copiosos governadores, prefeitos e outros agentes políticos, que argumentavam pelo excessivo rigor desta norma.

A LRF se baseou em experiências internacionais bem-sucedidas, a exemplo da Nova Zelândia, com o Fiscal Responsability Act, na União Europeia, a partir do Tratado de Maastricht e, nos Estados Unidos, com o Budget Enforcement Act, - de acordo com Nascimento e Debus (2002) - e o Program Assessment Rating Toll conforme Cavalcante (2010).

O Chefe do Poder Executivo tem, entre suas atribuições, a gerência da atividade financeira do Estado, que se constitui da busca de meios para satisfazer as necessidades públicas, no atingimento dos seus fins. Pode-se declamar, conforme está visível na Figura 1, que a atividade financeira do Estado se apresenta em obter, despender, gerir e criar, na medida em que corresponde, respectivamente, à receita pública, à despesa pública, ao orçamento público e ao crédito público. 
Figura 1. Atividade financeira do Estado

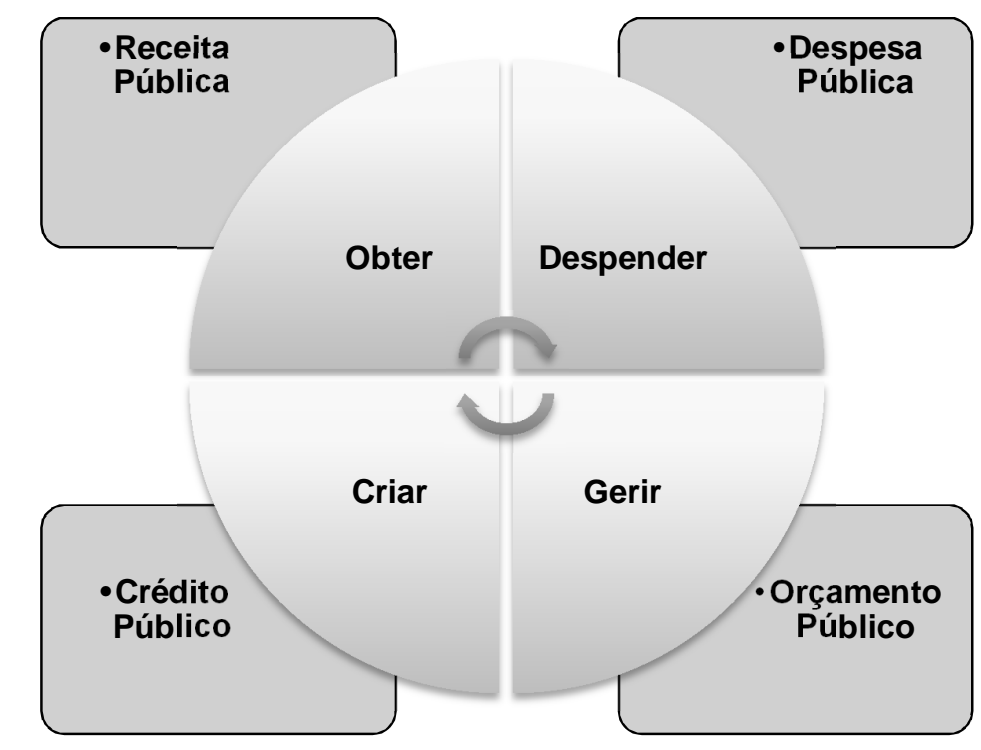

Fonte: Elaborada pelos autores a partir dos dados da pesquisa.

Dentro de uma visão holística, as atribuições do governo, difundidas por Musgrave (1973), exercem as funções na esfera distributiva, alocativa e

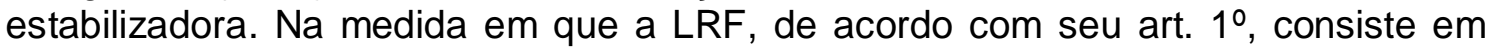
estabelecer normas de finanças públicas voltadas para a responsabilidade na gestão fiscal, compõe a normatização das três funções do governo. No momento em que o Brasil passou a utilizar um novo sistema para o regime de administração pública, conhecido como Regime de Gestão Fiscal Responsável, este foi fixado em três pilares, quais sejam: o planejamento, a transparência e o controle das contas públicas (BERLT; BENDER FILHO; TRISTÃO, 2017).

A LRF está dividida em dez capítulos, os quais instituem os procedimentos para que os gestores públicos adotem postura de verdadeiro administrador público. No ensinamento de Souza (2002), um bom administrador público se caracteriza pela capacidade de agir, adequadamente, diante de situações diversas, com inteligência prática, voltada à ação pública, desenvolvimento e aquisição de novos conhecimentos técnicos, por meio de uma constante capacitação, conhecimento das minúcias da gestão pública, habilidades interpessoais e, sobretudo, a liderança, que foi concedida, democraticamente, pelo sufrágio universal.

Esses dez capítulos da LRF sintetizam, em abrangência, o planejamento, a receita pública, a despesa pública, as transferências, o fomento, o endividamento, a gestão patrimonial, a accountability e considerações finais, conforme Figura 2. 
Figura 2. Síntese da LRF

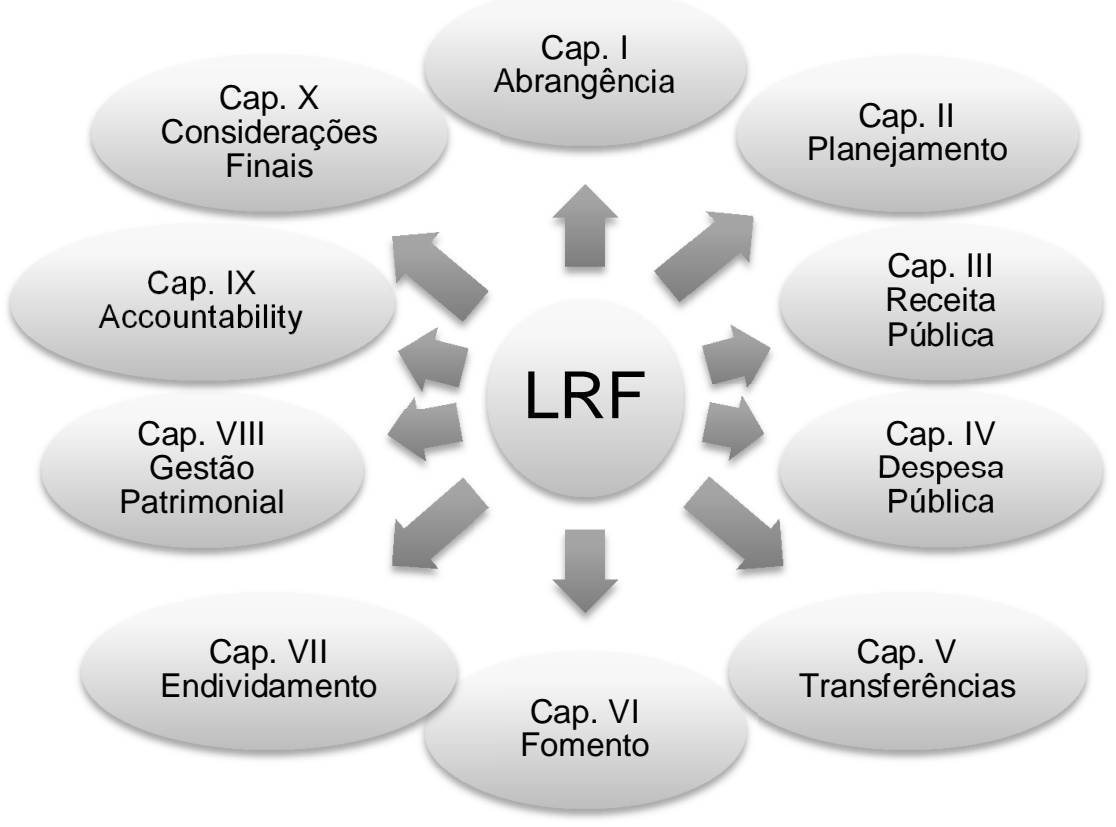

Fonte: Elaborada pelos autores a partir da LRF.

Como é o foco desta pesquisa, a LRF é uma ferramenta gerencial estratégica para impulsionar o desenvolvimento econômico social do Estado de Alagoas. Este desnuda as diretrizes para almejar tal proeza, bem como mecanismos estratégicos em redes com base normativa na LRF. Tais redes, por sua vez, têm sido apontadas como alternativas estratégicas para a sobrevivência do setor público. Nesse sentido, consistem em um formato que configura uma distinta estrutura organizacional pública, que ganhou notoriedade por combinar eficácia, informalidade e flexibilidade, rompendo com modelos ortodoxos da organização da Administração Pública. Conforme Araújo, Santos Filho e Gomes (2015), os instrumentos de planejamento e de execução das finanças públicas são essenciais à concepção, implantação, monitoramento e fiscalização de qualquer ação do Estado e devem estar em consonância com as necessidades da população, usuária dos serviços públicos prestados pelo Estado.

Compreender bem o ambiente externo é essencial, visto que o governo estadual não é agente que atua, isoladamente, no mercado e precisa atender as ações dos outros entes federativos, como na guerra fiscal, uma vez que além de entender o estado atual do ambiente envolvente, precisa, outrossim, projetar evoluções futuras e saber como estas afetaram a agenda de Políticas Públicas, pois todo ente público é um sistema aberto, que sofre influências externas, sendo alguns destes aspectos de natureza econômica, social, política, jurídica. Em todo caso, são variáveis que os Estados não possuem, ou dispõem de pouca capacidade de alterar. Ocorre que o monitoramento contínuo do ambiente é a chave na análise estratégica (SERRA et al, 2015).

Ademais, a Emenda Constitucional 86/2015 entrou em vigor e alterou a Constituição Federal de 1988, a partir de 17 de março de 2015. O objetivo desta emenda foi tornar obrigatória a execução da programação orçamentária. A emenda REUNA, Belo Horizonte - MG, Brasil, v.22, n.4, p.65-88, Out. - Dez. 2017 - ISSN 2179-8834 
promoveu alterações na redação dos artigos 165, 166 e 198 da CF/88, introduzindo modificações no sistema de execução orçamentária, com a finalidade de tornar obrigatória a realização de parte das despesas previstas na lei orçamentária. Os principais aspectos da nova redação da Constituição estão no artigo 165, parágrafos $9^{\circ}$ e 11 , ao prever $1,2 \%$ da receita corrente líquida para as emendas parlamentares individuais ao PLOA, que se torna de execução obrigatória, ressalvados apenas impedimentos de ordem técnica. No entanto, limitar essa obrigatoriedade às emendas parlamentares individuais é reduzir o alcance de uma medida, que deveria compreender todo o orçamento público e este, seguramente, é o principal entrave estratégico na implementação da discricionariedade de gestão do Poder Executivo.

Por fim, esta pesquisa está organizada em cinco seções: a introdução; a revisão teórica (considerações sobre os conceitos da Receita Corrente Líquida, sua evolução no Estado de Alagoas, a Regra de Ouro e as operações de crédito, a parte do endividamento da dívida consolidada e sua evolução); a terceira seção com a metodologia adotada; a quarta seção mostra o exame das ferramentas estratégicas da LRF, por meio dos planos plurianuais, diretrizes orçamentárias e o orçamento propriamente dito; a quinta e última seção engloba as considerações finais, oriundas dessa pesquisa.

\section{Revisão teórica}

Segundo Liu e Webb (2016), à medida que os governos subnacionais (SNGs) nos países em desenvolvimento e desenvolvidos ganharam mais autonomia fiscal responsabilidades de gastos, bases tributárias, transferências de receita do centro e capacidade de incorrer em dívidas - seu comportamento fiscal se tornou vital para o interesse nacional. Essas dívidas se tornam em financiamentos para suportar a infraestrutura social e econômica, podendo gerar retornos líquidos positivos e espalhar o fardo de financiamento de forma justa por gerações. Para Gordin (2016), quando os governos seguem políticas fiscais insustentáveis, prejudicam os serviços que administram, bem como a segurança do sistema financeiro, a credibilidade internacional dos países e a estabilidade macroeconômica. Muitas vezes, os governos são arrastados para fornecer resgates, o que pode prejudicar a própria sustentabilidade fiscal e recompensar as táticas fiscais populistas dos SNGs do destinatário. A crise financeira global de 2008-2010 testou a eficácia das regras fiscais na manutenção da disciplina fiscal e mostrou algumas desvantagens de rigidez face aos choques macroeconômicos (LIU e WEBB, 2016).

De acordo com Khair (2001), o surgimento da LRF trouxe vantagens à Administração Pública, tais como: transparência na gestão, maior eficiência na ação governamental, racionalização das despesas, crescimento das receitas, planejamento da ação do governo, herança fiscal. A LRF definiu o conceito de Receita Corrente Líquida (RCL), no seu art. $2^{\circ}$ como 0 somatório das receitas tributárias, de contribuições, patrimoniais, industriais, agropecuárias, de serviços, transferências correntes e outras receitas também correntes, deduzidas da seguinte maneira: provenientes da União, os valores transferidos aos Estados e Municípios por determinação Constitucional; dos Estados, as parcelas entregues aos Municípios por determinação Constitucional; e da União, dos Estados e dos Municípios, a 
contribuição dos servidores para o custeio do seu sistema de previdência e assistência social e as receitas provenientes da compensação financeira.

A RCL será apurada somando-se as receitas arrecadadas no mês em referência e nos onze anteriores, excluídas as duplicidades de modo que, no seu art. $12 \S 3^{\circ}$, o Poder Executivo de cada ente colocará à disposição dos demais Poderes e do Ministério Público, no mínimo, trinta dias antes do prazo final para encaminhamento de suas propostas orçamentárias, os estudos e as estimativas das receitas para 0 exercício subsequente, inclusive a RCL e as respectivas memórias de cálculo.

Não se deve confundir o conceito de Receita Pública com o conceito de Receita Corrente Líquida, compreendendo esta, conforme Castro (2013, p.287): "os recursos arrecadados pelo ente público de forma permanente, excluindo as receitas que possuem destino específico". Já aquela compreende, segundo Kohama (2009, p.60): "Todo e qualquer recolhimento feito aos cofres públicos, quer seja efetivado por meio de numerário ou outros bens representativos de valores".

$\mathrm{Na}$ medida em que a RCL serve de parâmetro para os limites estabelecidos pela LRF, sendo tais limites apresentados no Relatório Resumido da Execução Orçamentária (RREO), com a evolução nos últimos doze meses, assim como a previsão do desempenho que deve ser publicado até trinta dias após o encerramento de cada bimestre.

A regra de ouro de acordo com o art. 167 da CF/88 e do art. 6ำ da Resolução no 43/2001 do Senado Federal, a Regra veda a realização de operações de crédito que ultrapassam o montante das despesas de capital, objetivando evitar o exagerado endividamento dos entes da federação, por conseguinte, se torna uma ferramenta gerencial vinculada para não permitir a estagnação em termos de investimentos, nem comprometer o desenvolvimento do Estado.

Segundo Mendes (2015), essa Regra de Ouro objetiva que os entes da federação tenham suas finanças organizadas, que as receitas correntes sejam adequadas para atender as despesas correntes e, ainda, que sobrem recursos para investimentos no desenvolvimento socioeconômico.

Com isso, a Constituição proíbe que as receitas provenientes de operações de crédito não poderão ser superiores a todas as despesas de capital. A LRF define, em seu art. 29, que operações de crédito são os compromissos financeiros assumidos em razão de mútuo, de abertura de crédito, de emissão e aceite de título, de aquisição financiada de bens, de recebimento antecipado de valores provenientes da venda a termo de bens e serviços, arrendamento mercantil e outras operações assemelhadas, inclusive, com o uso de derivativos financeiros.

Nascimento e Debus (2002) explicam que para a solicitação de operações de crédito, a LRF determinou que se deva possuir parecer técnico contábil e jurídico, devendo ainda evidenciar a relação custo benefício, o interesse social e econômico, visando evitar o crescimento, sem planejamento, da dívida pública dos entes federados.

A Dívida Consolidada, segundo Kohama (2009), é aquela que representa um compromisso em longo prazo, de valor previamente determinado, garantida por títulos do governo, que rendem juros e são amortizáveis ou resgatáveis, podendo ou não o seu vencimento ser fixado. Já a LRF define, em seu art. 29: o montante total, apurado sem duplicidade, das obrigações financeiras do ente da Federação, assumidas em 
virtude de leis, de contratos, de convênios ou de tratados e da realização de operações de crédito, para amortização em prazo superior a doze meses e, ainda, as operações de crédito de prazo inferior a doze meses, cujas receitas tenham constado do orçamento.

Cabe ao Senado Federal a proposta de limites globais para o montante da Dívida Consolidada. De acordo com o art. 7, da Resolução 40/2001 do Senado Federal, a dívida consolidada líquida dos Estados não poderá exceder, no caso dos Estados, 2 (duas) vezes a receita corrente líquida.

\section{Metodologia}

O objetivo deste trabalho de natureza analítico-descritiva, no qual se esquadrinha em compreender as estratégias da Lei de Responsabilidade Fiscal como uma ferramenta gerencial estratégica, para impulsionar o desenvolvimento econômico social do Estado de Alagoas, mas também se faz a análise pragmática dos balanços orçamentários, patrimoniais, financeiros, planos plurianuais, diretrizes, leis orçamentárias, relatórios e anexos.

A pesquisa realizada se caracteriza por ser descritiva, com utilização da execução dos dados quantitativos e qualitativos. Os dados quantitativos estão relacionados à execução financeira dos orçamentos, diretrizes, planos plurianuais, anexos e relatórios, ou seja, são dados complementares relacionados às despesas fixadas e às receitas legalmente arrecadadas. Já os dados qualitativos estão relacionados às informações complementares referentes ao cumprimento das normas estabelecidas pela LRF, já que esta pesquisa visou apresentar o problema, sem maiores pretensões analíticas ou de generalizações científicas.

$\mathrm{Na}$ perquisição de informações para feitura do presente estudo, a pesquisa bibliográfica é forçosa, ou seja, é desenvolvida por meio de materiais já elaborados, geralmente, artigos científicos e livros, objetivando recolher informações e conhecimentos relacionados ao assunto a ser explorado (RAUPP E BEUREN, 2004). No que diz respeito à abordagem da adversidade do tema requer uma interpelação qualitativa, que visa destacar características não observadas em estudo quantitativo. Para Silva e Menezes (2001, p.20): "pesquisa qualitativa: considera que tudo pode ser quantificável, o que significa traduzir números em opiniões e informações para classificá-los e analisá-los".

Raupp e Beuren (2004, p.92) informam que "na contabilidade, é bastante comum o uso da abordagem qualitativa como tipologia de pesquisa. Cabe lembrar que, apesar de a contabilidade lidar intensamente com números, ela é uma ciência social, e não uma ciência exata como alguns poderiam pensar, o que justifica a relevância do uso da abordagem qualitativa". Com isso, faz-se necessário analisar, repensar e interpretar a realidade da organização como um todo, utilizando como técnica de pesquisa o estudo de caso, que permite executar vários conceitos, estudos e ouvir opiniões de quem resolveu, na prática, os problemas vistos na teoria. Gil (2009, p. 73) declara que: "O estudo de caso é caracterizado pelo estudo profundo e exaustivo de um ou de poucos objetos, de maneira a permitir conhecimentos amplos e detalhados do mesmo". 
Este estudo também se caracteriza como uma pesquisa exploratória, conforme (GIL, 2009), um vez que tem como objetivo proporcionar maior familiaridade com o problema, com vistas a torná-lo mais explícito, no caso em tela, evidenciar as ferramentas estratégicas da LRF como impulsionador do desenvolvimento econômico do estado de Alagoas. Foi utilizada ainda a pesquisa bibliográfica, no referencial teórico, com aprofundamento nos livros e artigos científicos referenciados.

Os dados da pesquisa foram coletados por meio de uma pesquisa documental. Segundo Silva (2010, p. 55): "a pesquisa documental difere da pesquisa bibliográfica por utilizar material que ainda não recebeu tratamento analítico ou que pode ser reelaborado, suas fontes são muito mais diversificadas e dispersas". Quanto à relação da coleta de dados, a pesquisa documental foi realizada por meio de averiguação em artigos, periódicos, leis, resoluções e portarias específicas.

Visando confirmar a Lei de Responsabilidade Fiscal como uma ferramenta estratégica, realizou-se uma pesquisa com balanços orçamentários, patrimoniais, financeiros, planos plurianuais, diretrizes, leis orçamentárias, relatórios e anexos do período de 2000 até agosto de 2017.

Esta pesquisa tem a finalidade de fornecer bases para futuros estudos mais analíticos sobre ferramentas estratégicas para o setor público, em decorrência da pouca presença deste tema e da falta de textos focados em estratégias para Administração Pública. Em relação ao método, esta pesquisa também utilizou dados históricos, em função de verificar e analisar situações ocorridas, desde a implementação da LRF até a última LDO aprovada. Esse método consiste em investigar acontecimentos, processos e instituições do passado para verificar a influência no presente.

\section{Resultados}

\subsection{Receita Corrente Líquida}

Desde a implementação da LRF, houve um grande aumento da RCL no Estado de Alagoas, conforme Gráfico 1. No ano 2000, o Estado de Alagoas possuía $R \$ 1,1$ bilhão, já em dezembro de 2016, o valor da RCL passou para $R \$ 7,6$ bilhões, um aumento de 539,34\%, confirmado por meio da normatização da LRF. O Estado de Alagoas conseguiu alavancar sua RCL, que é a base para estar dentro dos ajustes fiscais no tocante ao aumento da despesa de pessoal, bem como operações de crédito. Conforme o gráfico 1, apurada a RCL do Estado de Alagoas - com base no Relatório de Gestão Fiscal - permanece em uma tendência continuadamente de crescimento, apesar dos poucos investimentos estruturantes, o Estado está em curso do desenvolvimento econômico e social, mesmo que ainda longe do patamar desejado. 
Gráfico 1. Evolução da RCL

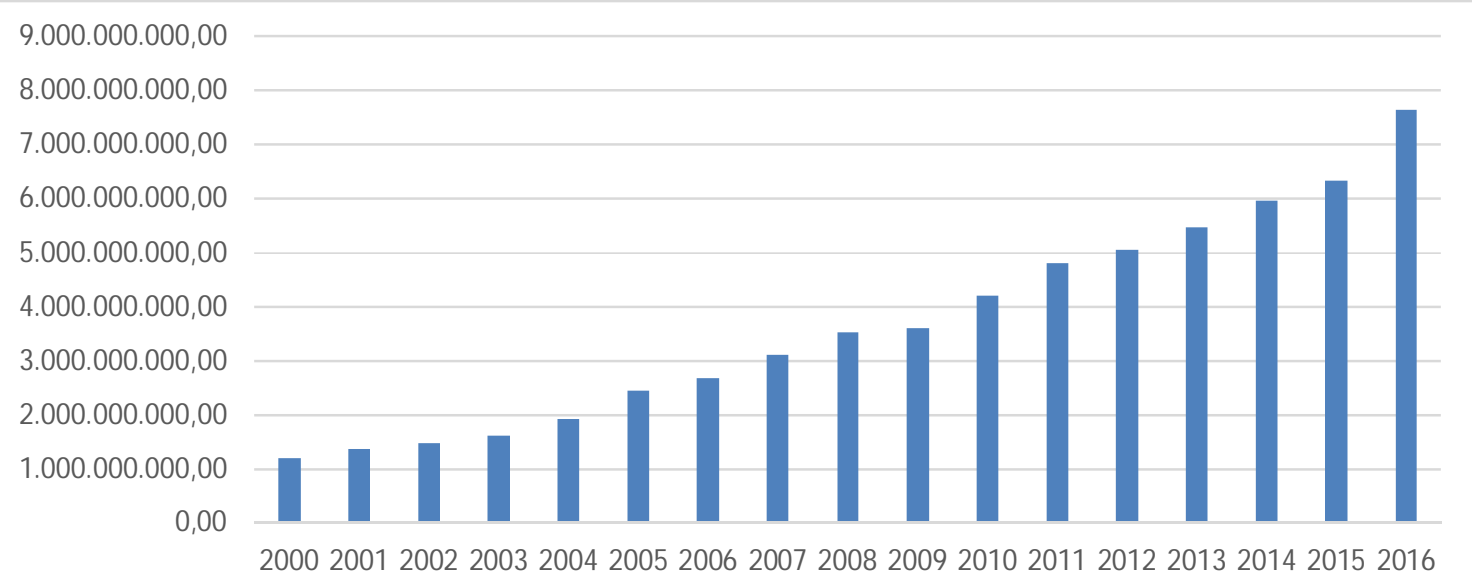

Fonte: Elaborado pelos autores com base no RGF

\subsection{Regra de Ouro}

Não obstante se esperar que a dívida pública não mais crescesse, nos últimos dois anos, 2015 e 2016, Alagoas voltou a receber recursos internacionais em operações de crédito, depois de três décadas em cumprimento da atual LRF, o que permitiu o pagamento de parte da dívida consolidada e a realização de alguns investimentos. Essas operações de crédito advieram da Caixa Econômica Federal ( $\mathrm{R} \$$ 313 milhões); do BNDES (R $\$ 90$ milhões) e (US\$ 250 milhões), sendo esta última a maior quantia recebida. Juntas, ocasionaram um aumento ainda maior da dívida pública do Estado de Alagoas, em mais de um bilhão de reais (CARVALHO, 2014).

Segundo Gomes (2014), essas operações de crédito entre os anos de 2000 (da implementação da LRF) e 2006 retiraram do erário alagoano $R \$ 1,8$ bilhão, com juros e amortizações e, entre os anos de 2007 a 2013, retiraram $R \$ 3,4$ bilhões, mais do que o dobro de juros e encargos da dívida do Estado de Alagoas com operações de crédito. Dos anos de 2000 a 2016, o pagamento com juros e encargos da dívida do Estado de Alagoas com operações de crédito chegou ao patamar de $R \$ 8$ bilhões.

A Regra de Ouro nunca foi um empecilho para o Estado de Alagoas, conforme se observa na tabela 1, visto que as operações de crédito sempre cumpriram o mandamento Constitucional. Desde a implementação da LRF, a ferramenta estratégica de operações de crédito vinha em uma escala constante de aumento, contudo, com a nova gestão essas despesas de capital começaram a ser reduzidas, sinalizando uma tendência a ser seguida nos próximos anos, conforme se pode observar também na Tabela 1. 
Tabela 1. Regra de Ouro

\begin{tabular}{r|r|r}
\hline Ano & $\begin{array}{c}\text { Despesa de Capital } \\
\text { Executada }\end{array}$ & $\begin{array}{c}\text { Operações de Crédito } \\
\text { Realizadas }\end{array}$ \\
\hline 2000 & $89.699 .258,97$ & $2.000 .000,00$ \\
2001 & $205.353 .000,00$ & $5.688 .000,00$ \\
2002 & $436.510 .019,82$ & $120.178 .872,42$ \\
2003 & $323.926 .890,30$ & $12.023 .988,75$ \\
2004 & $327.536 .458,72$ & $9.952 .870,13$ \\
2005 & $515.791 .355,00$ & $892.898,00$ \\
2006 & $426.522 .646,33$ & 0 \\
2007 & $446.522 .646,33$ & 0 \\
2008 & $704.068 .392,89$ & $3.997 .917,76$ \\
2009 & $1.084 .154 .827,23$ & $334.610 .060,38$ \\
2010 & $1.268 .987 .256,19$ & $199.468 .571,34$ \\
2011 & $1.064 .935 .103,47$ & $42.391 .823,42$ \\
2012 & $1.257 .554 .104,68$ & $17.722 .932,74$ \\
2013 & $1.338 .587 .876,98$ & $610.498 .657,95$ \\
2014 & $1.678 .620 .351,50$ & $554.477 .187,69$ \\
2015 & $1.041 .150 .555,35$ & $26.099 .378,91$ \\
2016 & $821.375 .732,97$ & $274.540,53$ \\
TOTAL & $\mathbf{1 3 . 0 3 1 . 2 9 6 . 4 7 6 , 7 3}$ & $\mathbf{1 . 9 4 0 . 2 7 7 . 7 0 0 , 0 2}$ \\
\hline
\end{tabular}

Fonte: Elaborado pelos autores com base no RREO

Destarte a regra de ouro analisada pelo Estado de Alagoas, significa que o déficit correspondeu ao endividamento público estadual dentro dos limites estipulados pela LRF, na medida em que serviu para financiar investimentos públicos necessários. Contudo, os gastos orçamentários, em despesa de capital, na natureza de investimento só tiveram aumento, a partir do exercício financeiro de 2014 sem comprometer o montante da dívida pública, que reduziu em 25,43\% do ano de 2015 para 2016, conforme tabelas 3 e 4.

Porém, 0 art. $7^{0}$ da Resolução 43/2001 do Senado Federal estabelece um percentual de $16 \%$ da RCL para operações de crédito dos entes da federação, que constitui essas operações de crédito, para os efeitos desta Resolução, os compromissos assumidos com credores situados no País ou no exterior, em razão de mútuo, de abertura de crédito, de emissão e aceite de título, de aquisição financiada de bens, de recebimento antecipado de valores provenientes da venda a termo de bens e serviços, de arrendamento mercantil e outras operações assemelhadas, inclusive, com o uso de derivativos financeiros, sendo este limite demonstrado na tabela 2.

$\mathrm{Na}$ medida em que mesmo considerando esta maior restrição, o Estado de Alagoas sempre esteve dentro do limite imposto pelo Senado Federal, curiosamente, a margem utilizada nas operações de crédito crescem em períodos de campanha política, contudo, esta nunca chegou ao patamar de $70 \%$ como a grande maioria dos Estados e capitais da federação brasileira. 
Tabela 2. Limite definido pelo Senado Federal Resolução 43/2001

\begin{tabular}{r|c|c|r|r}
\hline Ano & RCL & Permitido & $\begin{array}{c}\text { Operações de } \\
\text { Crédito Realizadas }\end{array}$ & Margem \\
\hline 2000 & $1.195 .875 .000,00$ & $191.340 .000,00$ & $2.000 .000,00$ & $1,05 \%$ \\
2001 & $1.375 .355 .000,00$ & $220.056 .800,00$ & $5.688 .000,00$ & $2,58 \%$ \\
2002 & $1.477 .875 .000,00$ & $236.460 .000,00$ & $120.178 .872,42$ & $50,82 \%$ \\
2003 & $1.619 .021 .000,00$ & $259.043 .360,00$ & $12.023 .988,75$ & $4,64 \%$ \\
2004 & $1.918 .255 .000,00$ & $306.920 .800,00$ & $9.952 .870,13$ & $3,24 \%$ \\
2005 & $2.442 .958 .506,00$ & $390.873 .360,96$ & $892.898,00$ & $0,23 \%$ \\
2006 & $2.674 .901 .792,00$ & $427.984 .286,72$ & 0 & $0,00 \%$ \\
2007 & $3.105 .363 .092,00$ & $496.858 .094,72$ & 0 & $0,00 \%$ \\
2008 & $3.528 .416 .000,00$ & $564.546 .560,00$ & $3.997 .917,76$ & $0,71 \%$ \\
2009 & $3.597 .964 .978,03$ & $575.674 .396,48$ & $334.610 .060,38$ & $58,12 \%$ \\
2010 & $4.205 .565 .036,63$ & $672.890 .405,86$ & $199.468 .571,34$ & $29,64 \%$ \\
2011 & $4.801 .098 .985,00$ & $768.175 .837,60$ & $42.391 .823,42$ & $5,52 \%$ \\
2012 & $5.051 .891 .183,67$ & $808.302 .589,39$ & $17.722 .932,74$ & $2,19 \%$ \\
2013 & $5.465 .256 .409,34$ & $874.441 .025,49$ & $610.498 .657,95$ & $69,82 \%$ \\
2014 & $5.969 .712 .767,26$ & $955.154 .042,76$ & $554.477 .187,69$ & $58,05 \%$ \\
2015 & $6.328 .523 .887,74$ & $1.012 .563 .822,04$ & $26.099 .378,91$ & $2,58 \%$ \\
2016 & $7.645 .675 .622,78$ & $1.223 .308 .099,64$ & $274.540,53$ & $0,02 \%$ \\
\hline \hline
\end{tabular}

Fonte: Elaborado pelos autores com base no RREO e RGF

\subsection{Limites com despesa de pessoal pela LRF}

A partir da edição da LRF, a criação, a expansão ou o aperfeiçoamento de ação governamental, que acarrete aumento de despesa, deverão estar acompanhados da estimativa de impacto orçamentário financeiro, com as premissas e metodologia de cálculos utilizadas no exercício, em que deva entrar em vigor e nos dois subsequentes. Ademais, deverão acompanhar a declaração do ordenador de despesa, cuja adequação orçamentária e financeira tem que ser compatível com o Plano Plurianual e com a Lei de Diretrizes Orçamentárias. Do mesmo modo, todo e qualquer aumento da despesa com pessoal deve obedecer à determinação da LRF, conforme art. 16.

Assim, a LRF estabeleceu uma regularidade quadrimestral para a aferição e supervisão do cumprimento dos limites máximos globais para as despesas de pessoal ativo e inativo de todos os Poderes e entes federativos, tal como previsto nos seus artigos 19 e 20. Visto que, a referida verificação no Estado de Alagoas fica a cargo do Tribunal de Contas Estadual, juntamente com o sistema de controle interno de cada Poder, pois essa verificação realizada ao final dos meses de abril, agosto e dezembro, na qual o artigo 18, $\S 2^{\circ}$ estabelece que a Despesa Total de Pessoal (DTP) será apurada, somando-se a realizada no mês em referência com as dos onze imediatamente anteriores, adotando-se o regime de competência. 
Destarte, outra ferramenta estratégica é o limite do gasto com DTP imposto pelo art. 19 da LRF, não obstante lembrar que o Governo é um prestador de serviços nato, principalmente, para a população mais carente. Em razão de os entes da federação comprometerem quase todas as suas receitas com o pagamento da folha com funcionários públicos, com o Estado de Alagoas não seria diferente, conforme gráfico 2, no qual se mostra o limite permitido de $60 \%$ da RCL em comparação com o DTP, obtido pelo RGF.

Gráfico 2. Evolução da RCL

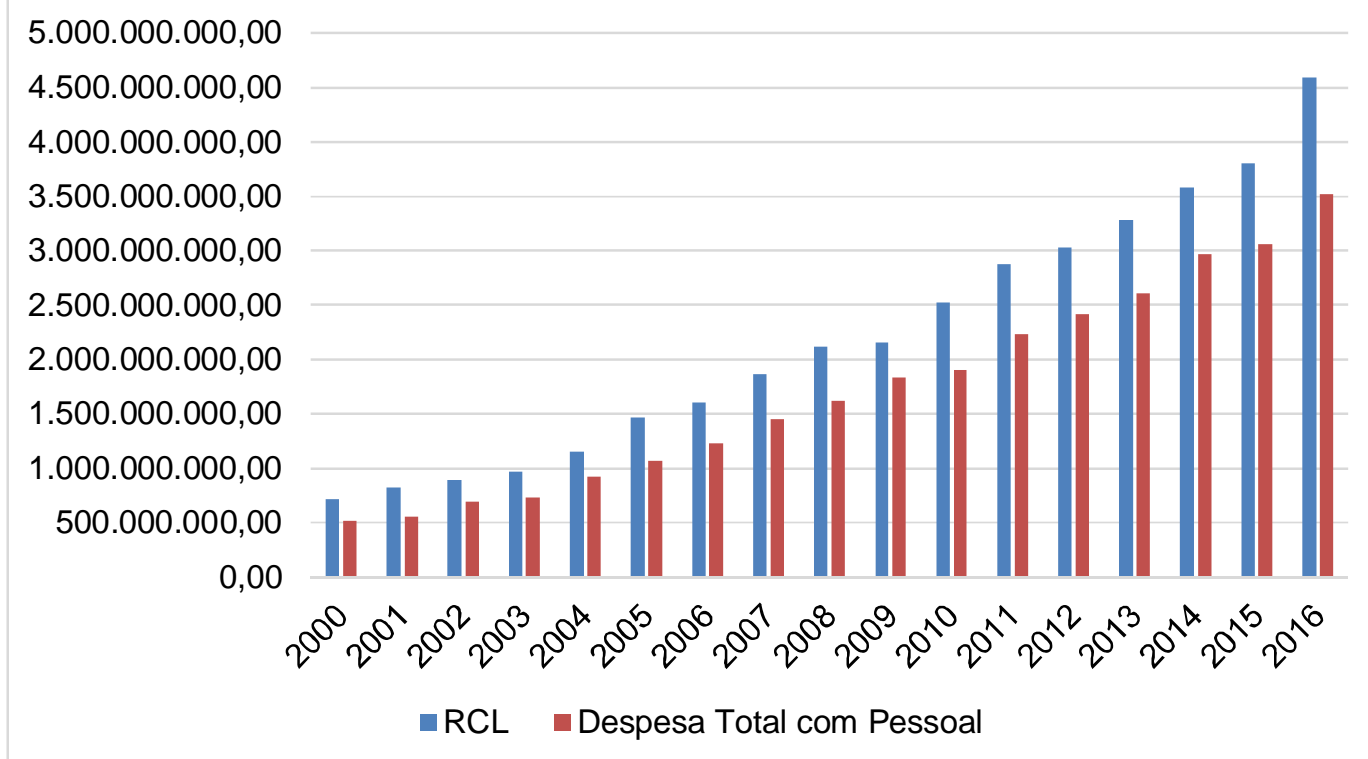

Fonte: Elaborado pelos autores com base no RGF

No ano de 2009, o Estado de Alagoas chegou perto do limite com gasto da despesa de pessoal pela RCL, fato que exigiu a solução estratégica adotada: a criação da AL Previdência pela Lei Estadual no 7.114/2009, com personalidade jurídica de direito privado e sem fins lucrativos, reestruturando o regime próprio de previdência. Desde sua criação até o segundo semestre de 2017, continua, entretanto, recebendo complemento financeiro do tesouro do Estado para cobertura de déficits, contudo, a Despesa Total com Pessoal (DTP) sempre esteve dentro do limite estipulado pela LRF.

A verificação do cumprimento dos limites será efetuada a cada quadrimestre, por meio do Relatório da Gestão Fiscal (RGF), pela Accountability Horizontal, ou seja, pela Assembleia Legislativa, pelo Tribunal de Contas do Estado e pela Controladoria Geral do Estado, sendo esta inoperante no desempenho do sistema de controle interno, na medida em que tanto a casa de contas como a controladoria nunca tiveram um concurso público para servidores na área técnica administrativa. Visto que, caso o limite não seja cumprido, a estratégia aponta para o fato de o excesso dever ser eliminado nos dois quadrimestres seguintes, sendo pelo menos um terço no primeiro. 
De fato, as estratégias, conforme a LRF, são as seguintes: redução de pelo menos $20 \%$ das despesas com cargos em comissão e função de confiança, exoneração dos servidores não estáveis e redução temporária da jornada de trabalho com adequação dos vencimentos à nova carga horária. Por fim, se a adoção dessas estratégias para redução com gasto, em despesa de pessoal, não resultar em diminuição dos excessos, o ente ficará proibido de receber transferências voluntárias; obter garantias, direta ou indireta, de outro ente da federação; contratar operações de crédito, salvo as destinadas ao refinanciamento da dívida mobiliária e as que visem redução de despesa com pessoal.

\subsection{Dívida Consolidada}

Conforme se pode observar na Tabela 3, há evolução da Dívida Consolidada do Estado de Alagoas, em paralelo com o limite estabelecido pela Resolução 40/2001 do Senado Federal, desde a implementação da LRF até o ano de 2016 e a margem de aumento ou diminuição.

Tabela 3. Limite definido pelo Senado Federal Resolução 40/2001

\begin{tabular}{ccc|c|r|r}
\hline Ano & RCL & Permitido & $\begin{array}{c}\text { Dívida Consolidada } \\
\text { Líquida }\end{array}$ & Margem \\
\hline \hline 2000 & $1.195 .875 .000,00$ & $2.391 .750 .000,00$ & $2.670 .510 .000,00$ & $11,66 \%$ \\
2001 & $1.375 .355 .000,00$ & $2.750 .710 .000,00$ & $2.451 .353 .000,00$ & $-10,88 \%$ \\
2002 & $1.477 .875 .000,00$ & $2.955 .750 .000,00$ & $3.491 .788 .000,00$ & $18,14 \%$ \\
2003 & $1.619 .021 .000,00$ & $3.238 .042 .000,00$ & $4.482 .250 .000,00$ & $38,42 \%$ \\
2004 & $1.918 .255 .000,00$ & $3.836 .510 .000,00$ & $5.072 .920 .000,00$ & $32,23 \%$ \\
2005 & $2.442 .958 .506,00$ & $4.885 .917 .012,00$ & $5.487 .783 .000,00$ & $12,32 \%$ \\
2006 & $2.674 .901 .792,00$ & $5.349 .803 .584,00$ & $5.927 .277 .000,00$ & $10,79 \%$ \\
2007 & $3.105 .363 .092,00$ & $6.210 .726 .184,00$ & $6.218 .123 .000,00$ & $0,12 \%$ \\
2008 & $3.528 .416 .000,00$ & $7.056 .832 .000,00$ & $6.955 .422 .000,00$ & $-1,44 \%$ \\
2009 & $3.597 .964 .978,03$ & $7.195 .929 .956,06$ & $6.509 .556 .000,00$ & $-9,54 \%$ \\
2010 & $4.205 .565 .036,63$ & $8.411 .130 .073,26$ & $6.798 .649 .000,00$ & $-19,17 \%$ \\
2011 & $4.801 .098 .985,00$ & $9.602 .197 .970,00$ & $7.099 .747 .000,00$ & $-26,06 \%$ \\
2012 & $5.051 .891 .183,67$ & $10.103 .782 .367,34$ & $7.599 .503 .000,00$ & $-24,79 \%$ \\
2013 & $5.465 .256 .409,34$ & $10.930 .512 .818,68$ & $7.998 .416 .495,90$ & $-26,82 \%$ \\
2014 & $5.969 .712 .767,26$ & $11.939 .425 .534,52$ & $9.540 .213 .509,39$ & $-20,09 \%$ \\
2015 & $6.328 .523 .887,74$ & $12.657 .047 .775,48$ & $10.555 .304 .801,52$ & $-16,61 \%$ \\
2016 & $7.645 .675 .622,78$ & $15.291 .351 .245,56$ & $7.871 .193 .569,82$ & $-48,53 \%$ \\
\hline \hline
\end{tabular}

Fonte: Elaborado pelos autores com base no RREO e RGF

Observa-se que após o ano de 2008, o Estado de Alagoas conseguiu estar dentro da meta estabelecida pela Resolução 40/2001 do Senado Federal, em relação à dívida consolidada líquida, fruto de grande esforço estratégico do governo para austeridade fiscal, com superávit primário de $R \$ 467,818$ milhões, evidenciando que 
o desempenho das receitas primárias permitiu a cobertura integral de toda a despesa primária, corrente e de capital, entretanto, este valor foi insuficiente para o pagamento do serviço da dívida, despesa com juros e amortização da dívida, conforme se observa na tabela 4 , no valor de $R \$ 498,216$ milhões, gerando um déficit nominal de $R \$ 30,398$ milhões, financiado por receitas financeiras de $R \$ 62$ milhões.

A Dívida Consolidada Líquida (DCL), no ano de 2008, atingiu o montante de $\mathrm{R} \$$ 6.955.422.000,00, equivalente a $197,13 \%$ da Receita Corrente Líquida (RCL), dentro do limite máximo de $200 \%$ estabelecido pela Resolução 40/2001 do Senado Federal, pela primeira vez desde a implementação da LRF, que no exercício de 2016, ficou abaixo da margem permitida, pela resolução do Senado Federal, foi a partir deste ano que a correlação da história começou a ser diminuída da DCL entre RCL.

A estratégia usada pelo governo nesse ano foi o reflexo do aumento em despesas com investimentos, um aumento significativo da receita tributária e, principalmente, das transferências federais e a ideia, que prepondera até o segundo semestre de 2017, de cortes excessivos nos gastos de custeio, de políticas públicas e com pessoal, com forte tendência de continuidade. Na meta de Resultado Nominal para o exercício de 2017 não foi previsto aumento da Dívida Fiscal Líquida, entretanto, no segundo quadrimestre de 2017, houve uma pequena redução da Dívida Fiscal Líquida, mas superando, portanto, a meta fiscal estabelecida na Lei Orçamentária Anual (LOA).

Tabela 4. Juros e Amortizações pagos e evolução da DCL

\begin{tabular}{ccccc}
\hline Ano & Juros/Amortizações pagos & Dívida Consolidada Líquida & Margem \\
\hline 2000 & $135.749 .647,93$ & $2.670 .510 .000,00$ & $5,08 \%$ \\
2001 & $181.226 .557,02$ & $2.451 .353 .000,00$ & $7,39 \%$ \\
2002 & $377.350 .165,84$ & $3.372 .025 .000,00$ & $11,19 \%$ \\
2003 & $245.370 .703,01$ & $4.482 .250 .000,00$ & $5,47 \%$ \\
2004 & $272.113 .268,51$ & $4.950 .116 .074,00$ & $5,50 \%$ \\
2005 & $363.262 .177,00$ & $5.487 .783 .127,00$ & $6,62 \%$ \\
2006 & $349.593 .002,94$ & $5.927 .277 .080,00$ & $5,90 \%$ \\
2007 & $477.866 .883,99$ & $6.218 .122 .699,00$ & $7,69 \%$ \\
2008 & $498.216 .604,31$ & $6.955 .421 .589,13$ & $7,16 \%$ \\
2009 & $648.402 .923,75$ & $6.509 .555 .507,62$ & $9,96 \%$ \\
2010 & $574.042 .729,00$ & $6.798 .649 .025,40$ & $8,44 \%$ \\
2011 & $683.106 .952,55$ & $7.099 .746 .949,87$ & $9,62 \%$ \\
2012 & $767.245 .774,21$ & $7.599 .502 .572,62$ & $10,10 \%$ \\
2013 & $691.253 .849,67$ & $7.998 .416 .495,90$ & $8,64 \%$ \\
2014 & $684.465 .846,93$ & $9.540 .213 .509,39$ & $7,17 \%$ \\
2015 & $824.802 .493,85$ & $10.555 .304 .801,52$ & $7,81 \%$ \\
2016 & $432.732 .570,80$ & $7.871 .193 .569,82$ & $5,50 \%$ \\
\hline \hline
\end{tabular}

Fonte: Elaborado pelos autores com base no RREO

REUNA, Belo Hor izonte - MG, Brasil, v.22, n.4, p.65-88, Out. - Dez. 2017 - ISSN 2179-8834 
Conforme se pode observar, na Tabela 4, a dívida pública alagoana vinha crescendo a cada ano e sufocando alternativas de investimentos, até chegar ao ápice de não ter apenas a contrapartida de alguns projetos em áreas fundamentais do Estado. O Projeto de Lei Orçamentária Anual (PLOA), para o ano de 2017, estima um pagamento de juros e amortização de exatamente $R \$ 853.201 .345,00$, a maior quantia já desembolsada da história para sanar a Dívida Consolidada.

Alagoas paga exorbitantes quantias de juros e amortizações de dívidas, sendo este sacrifício suportado pela sociedade atual. Para se ter uma ideia melhor dessa situação funesta, se somar, desde a implementação da LRF até o ano de 2017, tudo o que foi pago de juros e amortizações ( $R \$ 8,2$ bilhões) e, ainda, subtrair dessa conta as operações de crédito realizadas nesse período ( $R \$ 1,9$ bilhão), chega-se ao montante de $R \$ 6,3$ bilhões e, como a dívida pública alagoana, nesse mesmo período, passou de $R \$ 2$ bilhões para $R \$ 7,8$ bilhões, conforme tabela 4 .

As estratégias adotadas pelo governo eram de sanear as finanças públicas do Estado, por meio do ajuste estrutural, garantindo a geração de superávits fiscais nominais permanentes, entretanto, por terem sido elevados e expressivos os recursos orçamentários destinados para o pagamento dos seus encargos, como mostra a tabela 4, este estrangulou a capacidade de investimento do Estado, bem como a implementação de políticas públicas. Contudo, essa estratégia adotada tem impedido de continuar a trajetória de crescimento da dívida consolidada, mesmo com excessivos pagamentos de juros e amortizações, o Estado de Alagoas vislumbra, de fato, amortização da dívida pública, a fim de saná-la. Mesmo se o Estado deixasse de pagar todas as despesas, conforme o PLOA 2017 de $\mathrm{R} \$$ 8,5 bilhões, ainda não daria para sanar a dívida de $R \$ 7,8$ bilhões, ou seja, uma dívida praticamente impagável. Ano após ano, o Estado acaba devendo mais e este estoque da dívida consolidada só aumenta, contudo, com novo ajuste fiscal implementado, no exercício de 2016, se conseguiu reverter a trajetória de aumento.

Ombreia-se em relação ao aumento da Dívida Consolidada do Estado de Alagoas a seguinte conclusão: tendo em vista as condições decorrentes para obtenção de resultados imediatos e de curto prazo, impostos pela Lei no 9.496/97, foi utilizado o indexador IGP-DI mais juros de $7,5 \%$ ao ano e com $15 \%$ comprometidos da RCL estabelecido pelo Programa de Ajuste Fiscal, ou seja, essas condições impostas não foram suficientes para que Alagoas pudesse diminuir sua Dívida Consolidada; pior, fez com que chegasse a um patamar impagável.

Por fim, as perspectivas para o futuro do desenvolvimento do Estado de Alagoas são otimistas, pois em novembro de 2012, Alagoas conseguiu, por meio da Ação Ordinária no 1.726 no Supremo Tribunal Federal, a redução da taxa de juros do principal da dívida de $7,5 \%$ para $6 \%$ ao ano e o limite de comprometimento da RCL de $15 \%$ para $11,5 \%$. Outra boa perspectiva surgiu com a aprovação do Projeto de Lei Complementar n 99/2013, que altera o indexador da dívida, passando do atual IGPDI para o IPCA mais juros de $4 \%$ ou a Taxa Selic, dos dois, o menor, e com isso Alagoas está vivendo, ao contrário dos demais Estados da federação, uma folga orçamentária e financeira no exercício de 2017.

Portanto, Alagoas passou a ter uma redução de, aproximadamente, $\mathrm{R} \$ 1$ bilhão por ano, de tal sorte que essa mudança possibilita, estrategicamente, a capacidade de solicitar novos empréstimos para fomentar o desenvolvimento do Estado. Porém, em relação ao fluxo financeiro, haverá pouca mudança, pois o Estado continuará 
pagando, aproximadamente, $\mathrm{R} \$ 650$ milhões por ano e os efeitos positivos dessa alteração do indexador só terão impacto em aproximadamente oito anos.

\subsection{Ferramentas estratégias orçamentárias}

O Plano Plurianual (PPA), a Lei de Diretrizes Orçamentárias (LDO) e a Lei Orçamentária Anual (LOA) são leis que regulam o planejamento e o orçamento do Estado de Alagoas, como de qualquer outro ente federado e do próprio Governo Federal. Por outro lado, essas leis constituem etapas distintas, porém integradas, de forma que permitem um planejamento estruturado das estratégias governamentais, ressalta-se que não existe uma teoria unanimemente aceita sobre a criação de estratégias governamentais.

Foi somente após a Constituição Federal de 1988, que o PPA adentrou na fase de planejamento de médio e longo prazos, assim como a LDO foi uma inovação na Carta Magna. Sendo estas três leis orçamentárias estratégicas, o enfoque da LRF.

\subsubsection{Plano Plurianual}

O Plano Plurianual (PPA), como um instrumento de planejamento estratégico para médio e longo prazos, não apenas orçamentários, possibilita o controle das ações do governo, por conseguinte apresenta a visão de futuro para o país como para os Estados e municípios com macro desafios e valores, que guiam o comportamento para o conjunto da Administração Pública. Por meio dele, o Chefe do Poder Executivo declara e organiza sua atuação, a fim de elaborar e executar políticas públicas necessárias. O plano permite também que a sociedade tenha um maior controle sobre as ações concluídas pelo governo, uma vez que qualquer ação a ser desenvolvida deverá ser incluída no PPA, na forma de um programa orçamentário a ser executado ao longo da vigência do plano. Para a efetiva execução desse programa, será necessária sua inclusão na Lei Orçamentária Anual (LOA). O PPA, por outro lado, precisa ser feito com método, seguir um roteiro que pode ser comum para todos os entes federativos e ser executado em períodos específicos, conforme a legislação estadual de cada ente.

Segundo Giacomoni (2004), parte do esforço levado a efeito para enriquecer os planos plurianuais com metas físicas e indicadores de resultado será desperdiçada se não existirem formas de pactuação entre os que,se apresentam encarregados de enfrentar problemas, se responsabilizam ou pela formulação de políticas ou pela mobilização de recursos ou pela execução de programas e ações. Tendo por base os compromissos de todos, em face dos resultados pretendidos, os planos plurianuais, desde que devidamente articulados, se constituem nos instrumentos mais adequados para sediarem essa pactuação. No entanto, os Estados precisam ter um objetivo, algo que os alinhe a uma determinada meta, indique e avalie seu progresso, pois o PPA tem esta função, de modo que todos os agentes concentrem os seus esforços para alcançá-los. 
O desafio do planejamento estratégico para o Estado de Alagoas é a interligação das oportunidades de investimento nas diferentes realidades regionais. Tendo em vista que o desenvolvimento do Estado tem sido territorialmente desigual, segundo Carvalho (2014), a capital do Estado, Maceió, agrega 48\% do PIB alagoano.

O papel estratégico do PPA, nesse atual cenário, é de implementar a interligação dos planejamentos de longo prazo com a execução dos orçamentos anuais. Nesse ínterim, o PPA de Alagoas deve se constituir como um instrumento de coordenação entre todas as prefeituras, bem como no repasse dos recursos do Governo Federal. A arrecadação do seu principal imposto, o ICMS, não é suficiente para pagar as despesas com a folha de pagamentos, sendo os recursos do FPE a fonte para projetos de investimentos estruturantes, assim como discorre Abrucio (2007, p.76), nessa interligação: "o PPA está mais para um Orçamento Plurianual, na maioria dos governos. Para outros Estados, entretanto, trouxe inovações importantes, como a regionalização e a utilização de indicadores para nortear o plano plurianual".

Com o advento da LRF, desaparecem quaisquer justificativas para a não elaboração do PPA, permanecendo, entretanto, em face da ausência de norma adequada (GIACOMONI, 2004). Apenas o artigo terceiro da LRF versava, exclusivamente, sobre o PPA, não obstante foi vetado por conter, em seu texto normativo, que o envio do PPA pelo Poder Executivo ao Poder Legislativo deveria ocorrer até o dia 30 de abril, tornando-se um reduzido período para elaboração desta peça orçamentária, o que inviabilizaria o aperfeiçoamento metodológico e a seleção criteriosa dos programas e ações estratégicas.

Por fim, a importância estratégica do planejamento governamental está diretamente ligada ao ciclo de políticas públicas, a exemplo a agenda, a formulação, a implementação e a avaliação, na medida em que sem o correto planejamento estratégico, relacionado principalmente à etapa de formulação, a execução dos projetos fica prejudicada, ou até mesmo inviabilizada. Segundo Serra et al. (2015, p.14): "a realidade é que um processo de crescimento mal gerido pode originar sérias dificuldades do futuro".

Portanto, o planejamento com base no PPA é uma ferramenta estratégica para que os objetivos traçados, também na agenda de Políticas Públicas, pelo ator governamental, possam ser alcançados, visto que é o instrumento que organiza e ordena o que se pretende que aconteça, em determinado momento, pois o PPA é o documento que formaliza essa sistematização.

\subsubsection{Diretrizes Orçamentárias}

Inovação da atual Carta Magna, a LDO é o elo entre o planejamento estratégico (PPA), e o planejamento operacional (LOA). Parte dos doutrinadores afirma que a vigência da LDO é de apenas um ano, porém a LDO extrapola o exercício financeiro, uma vez que esta é devolvida para aprovação até o dia 30 de julho, conforme Constituição do Estado de Alagoas. Segundo Mendes (2015, p.46): "a LDO elaborada em 2015 terá vigência já em 2015 para que oriente a elaboração da LOA e também durante todo o ano de 2016, quando ocorrerá a execução orçamentária". 
A LRF aumentou o rol de funções da LDO, como por exemplo: o equilíbrio entre receita e despesas, que antes era sempre desrespeitado; os critérios e a forma de limitação de empenho, as normas relativas ao controle de custos e avalição dos programas e demais condições exigidas para transferências de recursos. No caso de não haver equilíbrio entre receita e despesa, no caso de a realização da receita não comportar as metas do resultado primário, haverá responsabilização do gestor competente, se esta for menor que a prevista na LDO e, se for superior, certamente, terá havido contingenciamento de empenhos ou inexecução de políticas públicas PINTO (2006).

De acordo com o artigo 4ํ da LRF, integrará a LDO, o Anexo de Metas Fiscais (AMF), cujas metas anuais serão estabelecidas relativas às receitas e despesas, aos resultados primário e nominal e, ainda, ao montante da dívida pública. As metas devem ser estimadas para o exercício a que se refere e para os dois seguintes, contendo a avaliação do cumprimento das metas relativas do ano anterior; o demonstrativo das metas anuais, com memória e metodologia de cálculo, comparado aos três exercícios anteriores e evidenciando as premissas e os objetivos da política econômica; a evolução do Patrimônio Líquido, nos três últimos exercícios; a avaliação da situação financeira e atuarial e o demonstrativo da estimativa e compensação da renúncia de receita e da margem de expansão das despesas obrigatórias de caráter continuado.

Ressalta-se que, além das metas futuras, a LRF determina que a LDO contenha uma avaliação dos resultados passados, o que gera subsídios para o planejamento estratégico consistente das metas a serem alcançadas. Por outro lado, as diretrizes orçamentárias dependem da análise e busca que, a partir de objetivos predeterminados, sejam definidas e implantadas as ações e as alocações dos recursos, por meio das leis orçamentárias.

Por fim, além do AMF, a LRF instituiu que a LDO deverá conter o Anexo de Riscos Fiscais (ARF), em que serão avaliados os passivos contingentes e outros riscos capazes de afetar as contas públicas, informando as providências a serem tomadas, caso tais riscos se concretizem. Existem dois riscos fiscais: o orçamentário e o risco da dívida. O primeiro está relacionado à possibilidade de as receitas e as despesas projetadas, na elaboração do PLOA, não se confirmarem durante 0 exercício financeiro.

O segundo está diretamente relacionado às flutuações de variáveis macroeconômicas, tais como: taxa básica de juros, variação cambial e inflação. Os riscos da dívida são derivados da dívida pública da União, que está associada ao pagamento de juros. Dessa forma, em situações em que é grande a probabilidade de, no ano vindouro, ocorrerem alterações positivas nas taxas de juros, este aumento de despesa deverá estar previsto no Anexo de Riscos Fiscais.

\subsubsection{Orçamentos Anuais}

A Lei Orçamentária Anual (LOA), basicamente, consolida todo o planejamento orçamentário de curto prazo, fixando as despesas e estimando as receitas para um exercício financeiro, período que coincide com o ano civil (PINTO, 2006). A finalidade da LOA é a concretização das estratégias e metas estabelecidas no PPA, sendo o cumprimento anual uma das etapas do planejamento. Destarte que, orientada pelas 
diretrizes, objetivos e metas, esta lei compreende ações a serem executadas pelas metas e prioridades da LDO.

À medida que a LOA compatibiliza as estratégias do PPA aos recursos disponíveis, por meio da previsão das receitas e da fixação das despesas públicas na peça orçamentária, (GIACOMONI, 2012), a estimativa das receitas e a autorização para a realização de despesas públicas são realizadas para o cumprimento de diversas finalidades, em cada exercício financeiro, que coincide com o ano civil. Portanto, o orçamento público é autorizativo, não impositivo, peculiaridade que a Proposta de Emenda à Constituição n 565/2006 pretende introduzir. A LRF trata da LOA, no seu artigo 5ำ, e esta será elaborada de forma compatível com o PPA e com a LDO, contendo a Reserva de Contingência para atender possíveis perdas em situações emergenciais, bem como para abertura de créditos adicionais. Nesse mesmo artigo, a LRF dá importância à dívida pública, com seu refinanciamento constando separadamente da LOA.

Contudo, as estratégias adotadas pelos titulares do Poder Executivo do Estado de Alagoas, nos últimos anos, foram de superestimar a receita nas LOA, além da capacidade real de arrecadação, desde o ano de 2002, conforme tabela 5, para também superestimar as despesas, sendo uma verdadeira manobra orçamentária em desrespeito aos ditames legais da LRF.

Tabela 5. Superestimação das receitas orçamentárias

\begin{tabular}{rcccr}
\hline \multicolumn{1}{l}{ Ano } & $\begin{array}{c}\text { Previsão } \\
\text { atualizada }\end{array}$ & $\begin{array}{c}\text { Receitas } \\
\text { realizadas }\end{array}$ & $\begin{array}{c}\text { Despesas } \\
\text { empenhadas }\end{array}$ & \multicolumn{1}{c}{ Diferença } \\
\hline 2001 & $1.590 .857 .000,00$ & $1.636 .156 .000,00$ & $1.403 .623 .000,00$ & $-2,77 \%$ \\
2002 & $2.005 .804 .000,00$ & $1.926 .166 .000,00$ & $1.852 .216 .000,00$ & $4,13 \%$ \\
2003 & $2.309 .238 .000,00$ & $2.136 .605 .000,00$ & $2.046 .103 .000,00$ & $8,08 \%$ \\
2004 & $3.048 .404 .000,00$ & $2.516 .921 .000,00$ & $2.320 .161 .000,00$ & $21,12 \%$ \\
2005 & $3.632 .780 .327,00$ & $3.125 .777 .404,00$ & $2.523 .293 .770,00$ & $16,22 \%$ \\
2006 & $3.384 .693 .775,00$ & $3.136 .475 .948,00$ & $2.815 .933 .864,00$ & $7,91 \%$ \\
2007 & $4.523 .780 .940,00$ & $3.749 .124 .297,00$ & $3.561 .061 .617,00$ & $20,66 \%$ \\
2008 & $4.960 .675 .349,00$ & $4.293 .548 .736,00$ & $4.254 .602 .634,00$ & $15,54 \%$ \\
2009 & $6.196 .622 .381,43$ & $4.731 .467 .591,32$ & $4.878 .337 .694,69$ & $30,97 \%$ \\
2010 & $6.472 .684 .100,11$ & $5.650 .378 .176,97$ & $5.557 .450 .464,67$ & $14,55 \%$ \\
2011 & $5.902 .444 .326,67$ & $5.669 .104 .344,80$ & $5.751 .480 .507,97$ & $4,12 \%$ \\
2012 & $7.109 .886 .444,23$ & $6.143 .838 .609,93$ & $6.478 .573 .042,80$ & $15,72 \%$ \\
2013 & $6.558 .312 .161,01$ & $6.242 .240 .639,74$ & $7.014 .443 .239,08$ & $5,06 \%$ \\
2014 & $8.674 .834 .219,89$ & $7.809 .789 .329,24$ & $8.121 .632 .937,95$ & $11,08 \%$ \\
2015 & $8.674 .962 .572,22$ & $7.800 .334 .345,50$ & $7.841 .439 .676,33$ & $11,21 \%$ \\
2016 & $8.781 .416 .147,46$ & $9.368 .775 .211,86$ & $8.538 .299 .011,84$ & $-6,27 \%$ \\
\hline \hline
\end{tabular}

Fonte: Elaborado pelos autores com base no RREO 
Portanto, o Poder Legislativo, encarregado da autorização da LOA, tem a capacidade de analisar os pressupostos das decisões, que promovem a superestimava das receitas, o redesenho das despesas e as alterações no curso da execução orçamentária, de acordo com a LOA (PINTO, 2006). Já a pesquisa, realizada por Vecchia e Montoya (2002), revelou que o orçamento autorizado pelo Poder Legislativo, normalmente, não expressa a verdadeira capacidade de arrecadação do erário, pois quanto maior a utilização de créditos adicionais, maior é o grau de ineficiência do planejamento orçamentário.

\subsection{Estratégias no último ano de mandato pela LRF}

Antes da LRF, via-se que no último ano de mandato, o gestor público deixava uma enorme dívida para seu sucessor ou simplesmente sem disponibilidade de caixa no curto prazo, fazendo com que o novo gestor público trabalhasse apenas para saldar dívidas contraídas com fito eleitoral. Após a LRF, essa prática frívola ficou proibida e, posteriormente, caracterizada por crime fiscal, por meio da Lei $n^{0}$ 10.028/2000, punindo o gestor com pena de reclusão de um a quatro anos.

As operações de Antecipação de Receitas Orçamentárias (ARO), para atender à insuficiência de caixa durante o exercício, não poderão ser realizadas no último ano do mandato do chefe do Poder Executivo.

Nenhuma despesa poderá ser contraída, bem como aumentada, nos dois últimos quadrimestres do mandato de qualquer titular dos Poderes, sem adequada e suficiente disponibilidade de recursos para o seu atendimento, seja dentro do exercício financeiro, seja para valores pagos no exercício seguinte, desde que não existam recursos em caixa para tal finalidade, ainda que em caso de reeleição, tudo de acordo com o artigo 42 da LRF.

O equilíbrio das contas públicas é um dos princípios a ser buscado durante toda gestão do administrador, notadamente, no último ano de mandato, mais precisamente nos últimos oito meses, o gestor deverá elaborar, estrategicamente, o fluxo de caixa do erário, não apenas passivo e adaptativo, estabelecendo a programação financeira com os desembolsos das despesas correntes. Os restos a pagar devem ter cobertura suficiente, pelo regime de caixa e não da competência, com a provisão de recursos financeiros para pagamento na época oportuna, outrossim, não se pode dar prioridade às dívidas contraídas nos últimos oito meses, deixando as outras despesas com prazo superior para futuro pagamento do seu sucessor, dessa forma, fazendo uma manobra contábil que ludibria o artigo 42 da LRF.

Portanto, as estratégias, principalmente, no último ano de mandato, não devem ser estáticas, mas devem ser ajustadas à medida que sua implementação evolui em função de oportunidades emergentes (SERRA et al, 2015).

\section{Considerações Finais}

O objetivo deste trabalho foi realizar uma pesquisa com todas as ferramentas estratégicas da Lei de Responsabilidade Fiscal (LRF), com foco no Estado de Alagoas, desde a implementação da LRF até o segundo semestre de 2017 e 
perspectivas para 2018. Os dados foram obtidos, em conformidade com os balanços orçamentários, patrimoniais, financeiros, planos plurianuais, diretrizes, orçamentárias, relatórios, leis, decretos, portarias, relatórios e anexos.

Passaram-se dezessete anos desde a implementação da LRF, tempo este suficiente para ultrapassar a fase de diagnósticos, e o titular do Poder Executivo usar das suas redes de ferramentas estratégicas propostas e assumir posicionamentos. Requer que não seja apenas um mero ordenador de despesas ou arrecadador de tributos, mas sim que todos os seus atos sejam processados de forma planejada, responsável e transparente.

Conforme evidenciado, os cidadãos alagoanos estão pagando um preço alto em função de gestores negligentes perante o erário, pelo aumento exponencial da dívida consolidada líquida, ficando 0 atual $e$ os futuros gestores públicos impossibilitados de maximizar as ferramentas estratégicas necessárias para a gestão governamental, ferramentas estas que devem ser sempre questionadas, pois podem se tornar obsoletas.

Em especial, a pesquisa contribuiu para ampliar a visão sobre a importância da avaliação da LRF, com o intuito de traçar um diagnóstico em consonância com a realidade vivenciada pelo Poder Executivo do Estado de Alagoas, possibilitando, assim, a definição de um planejamento, que resulte em ferramentas de ações corretivas orçamentárias.

Destarte, sugere-se a realização de novos estudos avaliativos com metodologia semelhante à adotada neste trabalho, a fim de verificar a possibilidade de confirmar $\mathrm{e}$ comparar os resultados. Outras dimensões de análise, como, por exemplo, um estudo da relação custo-benefício das ferramentas propostas pela LRF são outras opções para pesquisas futuras, considerando os apontamentos referentes ao pouco controle do erário. Também, ressalta-se a importância da realização constante e sistemática de estudos, que busquem avaliar a transparência dos recursos financeiros, para investigar os resultados e os impactos da política pública na melhoria dos serviços públicos prestados à comunidade, conforme preconiza a LRF. Além disso, os resultados não podem ser generalizados, uma vez que o estudo se limitou ao universo pesquisado, por meio de estudo de caso no Estado de Alagoas.

Portanto, a LRF não é a solução definitiva para a organização das finanças públicas do Estado de Alagoas ou para qualquer ente federado, entretanto, conforme foi demostrado, está sendo um grande avanço para o desenvolvimento e para accountability. Pode-se dizer que a sociedade alcançará um nível de cobrança a partir do momento em que for para as ruas para questionar esse montante de 8,2 bilhões de reais, desde a implementação da LRF até hoje, que já suportou com os pagamentos de juros e amortizações. Sabe-se que esta conta nunca irá fechar nos moldes dos indexadores vinculados, na medida em que essa dívida se encontra em aproximadamente 7,8 bilhões de reais, por conta das irresponsabilidades dos gestores passados, sobrecarregando atualmente as finanças públicas do Estado e, principalmente, das gerações futuras.

Por fim, cabe ao atual e aos futuros chefe do Poder Executivo, a grande responsabilidade de reverter esse quadro, na busca do equilíbrio fiscal sustentado, estrategicamente, com as ferramentas apresentadas nesta pesquisa, com base na LRF, objetivando impulsionar o crescimento do Estado de Alagoas. 


\section{REFERÊNCIAS}

ABRUCIO, F. L. Trajetória recente da gestão pública brasileira: um balanço crítico e a renovação da agenda de reformas. Revista de Administração Pública, Rio de Janeiro v. 41, n. esp. p. 67-86, 2007.

ALBUQUERQUE, C.; MEDEIROS, M.; FEIJÓ, P. H. Gestão de finanças públicas. $2^{a}$ ed. Brasília: Gestão Pública, 2008.

ARAÚJJ, A. H. D. S.; SANTOS FILHO, J. E. D.; GOMES, F. G. Lei de Responsabilidade Fiscal: efeitos e consequências sobre os municípios alagoanos no período 2000-10. Revista de Administração Pública, v. 49, n. 3, p. 739-759, 2015.

AVERBUG, A.; GIAMBIAGI, F. A crise brasileira de 1998/1999: origens e consequências. Rio de Janeiro, BNDES, 2000.

AZEVEDO, R. R.Uma análise dos índices da lei de responsabilidade fiscal nos municípios paulistas após a implantação do projeto AUDESP. Revista de Gestão, Finanças e Contabilidade, v. 3, n. 2, p. 39-60, 2013.

BARBOSA, J. L. R.; LUNA, C. M.; SOUZA, G.; MANTOVANI, P. D. R. Finanças Públicas: estudo sobre a LRF no Município de Mauá. Revista Eletrônica Gestão e Serviços, v. 5, n. 1, p. 719-742, 2014.

BERLT, C.; BENDER FILHO, R.; TRISTÃO, P. A. Gastos Públicos: Análise da Aplicação da Lei de Responsabilidade Fiscal e da Constituição Federal no Corede Alto Jacuí. Revista de Administração da UFSM, v. 10, n. 1, p. 85-100, 2017.

BERNARDO, J. S.; REIS, A. O.; SEDIYAMA, G. A. S. Características Explicativas do Nível de Transparência na Administração Pública Municipal. Revista Ciências Administrativas, v. 23, n. 2, p. 277-292, 2017.

BRASIL. República Federativa do. Constituição Federal. Brasília: Centro Gráfico do Senado Federal, 1988.

<http://www.planalto.gov.br/ccivil_03/leis//4320.htm>. Acesso em 01/08/2017

. Lei Complementar no 101, de 4 de maio de 2000. Disponível em: <http://www.planalto.gov.br/ccivil_03/leis/lcp/lcp101.htm>. Acesso em 01/08/2017

CASTRO, D. P. de. Auditoria, Contabilidade e Controle Interno No Setor Público. 5ª ed. São Paulo: Atlas, 2013.

CARVALHO, C. P. Economia Popular uma via de modernização para Alagoas. $6^{a}$ ed. Maceió: Edufal, 2014.

CARVALHO, D. LRF Doutrina e Jurisprudência. Rio de Janeiro: Elsevier, 2009. 
CAVALCANTE, P. L. Orçamento por Desempenho: uma análise qualitativa comparada dos modelos de avaliação dos programas governamentais no Brasil e nos Estados Unidos. Revista de Gestão, v. 17, n. 1, art. 2, p. 13-25, 2010.

CRUZ, F.; VICCARI, A, J.; GLOCK, A, O.; HERZMANN, N.; TREMEL, R.; Lei de Responsabilidade Fiscal Comentada. 9ª ed. São Paulo: Atlas, 2014.

GERIGK, W.; RIBEIRO, F.; SANTOS, L. M. D. O padrão de endividamento dos estados da região sul e a sua dinâmica após a edição da lei de responsabilidade fiscal por meio de índices-padrão. Revista Catarinense da Ciência Contábil, v. 13, n. 39, p. 34-48, 2014.

GIACOMONI, J. Orçamento público. 16ª ed. São Paulo: Atlas, 2012.

; Bases normativas do plano plurianual: análise das limitações decorrentes da ausência de lei complementar. Revista de Administração Pública, v. 38, n. 1, p. 79-91, 2004.

GIAMBIAGI, F.; ALÉM, A. Finanças Públicas 4ํㅜ ed. Rio de Janeiro: Elsevier, 2011.

GIL, A. C. Como elaborar projetos de pesquisas. São Paulo: Atlas, 2009.

GOMES, F. G. Ensaios sobre o subdesenvolvimento e a economia política contemporânea. $1^{\text {a }}$ ed. São Paulo: Hucitec, 2014.

GORDIN, J. P. Federalism and the politics of fiscal responsibility laws: Argentina and Brazil in comparative perspective. Policy Studies, v. 37, n. 3, p. 236-253, 2016.

KHAIR, A. A. Gestão Fiscal responsável. Guia de Orientação para as Prefeituras. Conselho Regional de Contabilidade do Rio Grande do Sul. Porto Alegre, Rs: 2001.

KOHAMA, H. Contabilidade Pública - Teoria e Prática. 10ª ed. São Paulo: Atlas, 2009.

LAUREANO, R. V.; WARTCHOW, D.; ROSSO, V. P.; MACAGNAN, C. B. Divergências entre o Posicionamento dos Auditores Públicos e dos Conselheiros do TCE-RS na Análise da LRF. Advances in Scientific and Applied Accounting, v. 10, n. 1, p. 91109, 2017.

LINHARES, F.; PENNA, C.; BORGES, G. Os efeitos da Lei de Responsabilidade Fiscal no endividamento dos municípios do Piauí. Revista de Administração Pública, v. 47, n. 6, p. 1359-1374, 2013.

LIU, L.; WEBB, S. B. Laws for fiscal responsibility for subnational discipline: international experience. Applied Economics and Finance, v. 3, n. 1, p. 118-137, 2016.

MAGRO, C. B. D.; SILVA, T. P. Desempenho dos gastos públicos em educação e a Lei de Responsabilidade Fiscal das capitais brasileiras. Contabilidade, Gestão e Governança, v. 19, n. 3, p. 504-528, 2016. 
MENDES, S. Administração Financeira Orçamentária. $5^{\text {a }}$ ed. Rio de Janeiro: Método, 2015.

MUSGRAVE, R. Teoria das Finanças Públicas. São Paulo: Atlas, 1973.

MÜLLER, A.; STORESLETTEN, K.; ZILIBOTTI, F. The political color of fiscal responsibility. Journal of the European Economic Association, v. 14, n. 1, p. 252302, 2016.

NASCIMENTO, E. R.; DEBUS, I. Lei Complementar no 101/2000: entendendo a lei de responsabilidade fiscal. Brasília: ESAF, 2002.

PINTO, E. G. Discricionariedade, contingenciamento e controle orçamentário. Revista Gestão \& Tecnologia, v. 6, n. 2, p. 1-24, 2006.

RAUPP, F. M.; BEUREN, I. M. (Org.). Como elaborar trabalhos monográficos em contabilidade: teoria e prática. 2. ed. São Paulo: Atlas, 2004.

SERRA, F. A. R; FERREIRA, M. P; TORRES, M. C. S; TORRESM A. P. Administração estratégica. 3ª̣ ed. Rio de Janeiro: Elsevier, 2015.

SILVA, A. C. R. Metodologia da pesquisa aplicada à contabilidade: orientações de estudo, projetos, artigos, relatórios, monográficas, dissertações, teses. $3^{\mathrm{a}}$ ed. São Paulo: Atlas, 2010.

SILVA, E. L.; MENEZES, E. M. Metodologia da pesquisa e elaboração de dissertação. 3. ed. Florianópolis: EDUFSC, 2001.

SOUZA, E. C. L. A capacitação administrativa e a formação de gestores governamentais. Revista de Administração Pública, v. 36, n. 1, p. 73-88, 2002.

VECCHIA, E. D.; MONTOYA, M.A. Orçamento e Planejamento Municipal: Um Estudo de Caso. Revista de Economia Política, vol. 22, no 2 (86), abril-junho/2002. 